\title{
The effects of protein degradability and food intake on milk yield and composition in cows in early lactation
}

\author{
BY E. R. ØRSKOV, G. W. REID AND I. MCDONALD \\ Rowett Research Institute, Bucksburn, Aberdeen AB2 9SB
}

(Received 1 May 1980 - Accepted 15 December 1980)

\begin{abstract}
1. In two experiments measurements were made of food intake, live-weight change, milk yield and milk composition in early lactation when dairy cows were given diets containing varying proportions of protein as fish meal (low rumen degradability) or as groundnut meal (high rumen degradability). In a preliminary trial measurements were also made with cows given supplements of either fish meal or barley and fed at a restricted level of feeding.

2. When metabolizable energy (ME) intake exceeded $160 \mathrm{MJ} / \mathrm{d}$ there was no evidence of responses to changes in protein degradability, but at ME intakes below $135 \mathrm{MJ} / \mathrm{d}$ increases in the supply of undegradable protein led to increases in fat-corrected milk yield, protein content and live-weight loss.

3. The interaction between energy intake and protein degradability is unexpected because net protein: net energy requirement increases as milk yield increases, but may be explained in terms of differential effects of changing rumen outflow rates on degradabilities.
\end{abstract}

New methods of estimating protein requirements for ruminants make it clear that the need for a source of protein which is relatively undegradable in the rumen increases with increasing milk yield (Ørskov, 1977; Roy et al. 1977; Kaufman, 1979; Oldham \& Sutton, 1979; Swan, 1979). Whereas dairy cattle may have considerable reserves of body fat which can be mobilized in early lactation to meet deficits in energy supply (Flatt et al. 1967), it is generally considered that, relatively, very limited amounts of body protein can be drawn upon when dietary protein supply is inadequate. Both for ewes (Robinson et al. 1974) and for cows (Ørskov et al. 1977) it has been shown that a higher dietary protein concentration is required when animals are in negative energy balance and that additional protein appears to facilitate greater mobilization of body fat. In the experiment reported by Ørskov et al. (1977), Friesian cows in early lactation were given amounts of food sufficient to provide for a daily yield of only $10 \mathrm{~kg}$ fat-corrected milk (FCM), and were given post-ruminal infusions of casein or glucose. Glucose appeared to have no effect but casein infusion increased FCM yield by $7 \mathrm{~kg} / \mathrm{d}$, which in turn increased the calculated deficit of metabolizable energy (ME) from 20 to $40 \mathrm{MJ} / \mathrm{d}$.

The need to achieve a high peak-milk yield, in order to make possible a high whole-lactation yield, has been well documented (Broster, 1972), and is a further argument for the importance of dietary protein quality in early lactation. A series of three experiments has been carried out with dairy cattle during the first weeks of lactation to compare the effects of diets containing proteins of either high or low rumen degradability on milk yield and body-weight change. In the last two experiments the diets were completely mixed and were given ad lib., while in the first experiment intakes were restricted.

\section{MATERIALS AND METHODS \\ Expt 1}

Animals and treatments. Twenty Friesian cows, with live weights of approximately $600 \mathrm{~kg}$ after calving in spring 1977, were allocated at random to either a control diet (B) or to a $\operatorname{diet}(\mathrm{F})$ which was prepared by substituting $1 \mathrm{~kg}$ fish meal for the same quantity of barley/d.

Diets. All the cows were given a basal diet at the rate of $7 \mathrm{~kg} / \mathrm{d}$ in week 1 , rising by 
Table 1. Expts 2 and 3. Ingredients ( $\mathrm{g} / \mathrm{kg}$ dry weight), chemical composition $(\mathrm{g} / \mathrm{kg} d r y$ matter) and digestibility of organic matter $(\mathrm{g} / \mathrm{kg})$ in diets

\begin{tabular}{|c|c|c|c|c|c|c|c|}
\hline \multirow[b]{2}{*}{$\begin{array}{l}\text { Diet... } \\
\text { Ingredient }\end{array}$} & \multicolumn{3}{|c|}{ Expt 2} & \multicolumn{4}{|c|}{ Expt 3} \\
\hline & F & FG & $\mathbf{G}$ & HG & $\mathbf{H F}$ & LG & LF \\
\hline Hay & 400 & 400 & 400 & 500 & 500 & 700 & 700 \\
\hline Rolled barley & 480 & 462 & 445 & 345 & 380 & 145 & 180 \\
\hline Groundnut meal & & 48 & 95 & 95 & & 95 & \\
\hline White fish meal & 60 & 30 & & & 60 & & 60 \\
\hline Molasses & 40 & 40 & 40 & 40 & 40 & 40 & 40 \\
\hline Calcium carbonate & 5 & 5 & 5 & 5 & 5 & 5 & 5 \\
\hline Minerals and vitamins & 5 & 5 & 5 & 5 & 5 & 5 & 5 \\
\hline Urea & 8 & 8 & 8 & 8 & 8 & 8 & 8 \\
\hline Sodium sulphate & 2 & 2 & 2 & 2 & 2 & 2 & 2 \\
\hline Nitrogen & 25 & 24 & 27 & 21 & 22 & 20 & 21 \\
\hline Acid detergent fibre* & & & & 237 & 243 & 279 & 306 \\
\hline $\begin{array}{l}\text { Digestibility of organic } \\
\text { matter }\end{array}$ & & & & 696 & 681 & 654 & 662 \\
\hline
\end{tabular}

* Van Soest (1963).

$1 \mathrm{~kg} /$ week to $12 \mathrm{~kg} / \mathrm{d}$ in week 6 . In addition, cows were given daily $1 \mathrm{~kg}$ of either rolled barley with $10 \mathrm{~g}$ urea $/ \mathrm{kg}$ (diet B) or fish meal (diet F). The basal diet was made up of $600 \mathrm{~g}$ pelleted concentrate $(7.4 \mathrm{~mm}$ die) and $400 \mathrm{~g}$ hay $/ \mathrm{kg}$, the former containing 828 parts rolled barley, 147 parts groundnut meal, 10 parts mineral and vitamin mix and 10 parts limestone. The acid-detergent fibre (ADF; Van Soest, 1963) content of the basal diet was $215 \mathrm{~g} / \mathrm{kg}$. The concentrate contained 26 and the hay $14 \mathrm{~g} \mathrm{~N} / \mathrm{kg}$ dry matter.

Management. The cows were kept in individual stalls on rubber mats, given their feeds twice daily in equal amounts at 08.00 and 16.00 hours, and milked twice daily in a rotary milking parlour. Milk yields were recorded daily and weighted samples of the morning and evenings milkings taken twice weekly for the determination of nitrogen by the method of Davidson et al. (1970), of fat by the Gerber method, and of solids by the method of the Association of Official Agricultural Chemists (1965).

\section{Expt 2}

Animals and treatments. Thirty-six Friesian cows calving in spring 1978 were allocated at random to one of three completely-mixed diets based on concentrate and hay $(60: 40, w / w)$ and offered ad lib. The main protein source in the concentrate was fish meal (F), groundnut meal (G), or a 1:1 mixture of the two (FG).

Diets. The dietary ingredients are shown in Table 1, together with their average $\mathrm{N}$ contents. The hay was shredded through a bale grinder with a $5 \mathrm{~mm}$ screen and mixed with the concentrate in a mixer trailer.

Management. The diets were offered immediately following calving and for a period of 6 weeks. New food was introduced twice daily and the troughs were cleared once weekly. Milking arrangements and measurements were the same as for Expt 1 . The live weights of the cows were recorded each week.

\section{Expt 3}

Animals and treatments. Thirty-six Friesian cows calving in spring 1979, were allocated at random to four different diets, fed ad lib. The diets contained concentrates-hay $(50: 50(\mathrm{H})$ 
Table 2. Expt 1. Yields of milk and fat-corrected milk (FCM), milk composition, and dry matter intakes $(D M I)$ for cows on basal diets supplemented by $1 \mathrm{~kg}$ fishmeal $(F)$ or barley $(B) / d$

(Means with their standard errors for groups of ten animals)

\begin{tabular}{lcccccc}
\hline \hline Diet & $\begin{array}{c}\text { Milk yield } \\
(\mathbf{k g} / \mathbf{d})\end{array}$ & $\begin{array}{c}\text { FCM } \\
(\mathbf{k g} / \mathbf{d})\end{array}$ & $\begin{array}{c}\text { Milk fat } \\
(\mathrm{g} / \mathbf{k g})\end{array}$ & $\begin{array}{c}\text { Total } \\
\text { solids } \\
(\mathrm{g} / \mathbf{k g})\end{array}$ & $\begin{array}{c}\text { Milk N } \\
(\mathrm{g} / \mathbf{k g})\end{array}$ & $\begin{array}{c}\text { DMI } \\
(\mathbf{k g} / \mathbf{d})\end{array}$ \\
\hline F & 20.9 & 21.9 & 44 & 132 & 5.2 & 8.9 \\
B & 20.1 & 20.1 & 41 & 127 & 4.8 & 8.8 \\
SEM (df 18) & 0.47 & 0.50 & 1.1 & 1.1 & 0.05 & \\
\hline
\end{tabular}

or 30:70 (L), w/w); the concentrate mixture contained either fish meal $(F)$ or groundnut meal $(G)$ as the main source of protein.

Diets. Table 1 shows the ingredients of the four diets, together with the average $\mathrm{N}$ and ADF contents. The ingredients were mixed as complete diets as described for Expt 2.

Management. This was similar to Expt 2, but the experiment extended to 12 weeks after calving. For $8 \mathrm{~d}$ at the end of the experiment faeces were collected from three cows on each treatment, and digestibility was determined.

\section{RESULTS}

Expt 1. Mean values for milk yield, milk composition, and dry matter intake over weeks 1-6 of lactation are given for both dietary treatments in Table 2 . The provision of additional undegradable protein by substituting fish meal for barley did not significantly affect milk yield but the yield of FCM was increased $(P<0.05)$ due to the higher fat content $(P<0.05)$. The concentrations of protein $(P<0.001)$ and of solids $(P<0.01)$ in milk were also significantly higher on the fish meal diet. Treatment of individual cows for acetonemia ( $15 \mathrm{mg}$ betametasone) was necessary on several occasions with accompanying but temporary reductions in food intake. The number of occasions divided by the number of cows amounted to $0.8 /$ cow for both treatments.

Expt 2. The cows achieved high food intakes very rapidly after calving and completed the experiment in good health, treatment for acetonemia being required on only two cows during the whole experiment. The ME content of the diets was estimated to be $11.3 \mathrm{MJ} / \mathrm{kg}$ dry matter, based on the digestibilities measured in Expt 3 and assuming a digestible energy (DE):digestible organic matter (DOM) value of $19 \mathrm{MJ} / \mathrm{kg}$ and ME:DE of 0.89 reported by Flatt $e t$ al. (1967) for Friesian cows in early lactation given diets similar to those used here. There were no statistically significant treatment differences in the mean ME intakes, which are given in Table 3, together with mean ME deficits obtained by calculating the difference between ME intakes and calculated ME requirements for zero energy balance. The calculation was based on the assumption that daily maintenance requirement was $0.51 \mathrm{~W}^{0.75}(\mathrm{MJ})$ for a cow of live weight $\mathrm{W}(\mathrm{kg}$ ), that the energy value of $\mathrm{FCM}$ was $3.18 \mathrm{MJ} / \mathrm{kg}$ (Gaines \& Overman, 1938), and that $1.55 \mathrm{MJ}$ of $\mathrm{ME}$ was required per MJ secreted in milk. The ME deficits decreased from week 1-3 to week 3-6 of lactation and the differences between treatments were not significant.

The mean milk yields (Table 3) increased from weeks 1-3 to weeks 4-6. There were no significant treatment differences in the yields, nor in the contents of $\mathrm{N}$, fat and solids, which are also given in Table 3 for weeks 1-3 and for weeks 4-6.

Expt 3. The incidence of treatment for suspected acetonemia was low on the highconcentrate diets HG and HF, for which the frequency was only 0.1 per cow, but it was 
Table 3. Expt 2. Mean estimates of metabolizable energy (ME) intake and of deficit relative to MErequirement for zero energy balance, together with mean yields of milk and fat-corrected milk (FCM) and mean concentrations of fat, solids and nitrogen in milk for groups of twelve cows receiving as protein supplement either fish mean $(F)$, groundnut $(G)$ or a mixture of the two (FG) during weeks 1-3 and 4-6 of lactation

\begin{tabular}{|c|c|c|c|c|c|c|c|c|}
\hline \multirow{2}{*}{$\begin{array}{l}\text { Weeks... } \\
\text { Diet... }\end{array}$} & \multicolumn{4}{|c|}{$1-3$} & \multicolumn{4}{|c|}{$4-6$} \\
\hline & $\mathbf{F}$ & $\mathbf{F G}$ & $\mathbf{G}$ & $\begin{array}{c}\text { SEM } \\
\text { (df 33) }\end{array}$ & $\boldsymbol{F}$ & FG & $\mathbf{G}$ & $\begin{array}{c}\text { SEM } \\
\text { (df 33) }\end{array}$ \\
\hline ME intake (MJ/d) & 146 & 143 & 141 & $4 \cdot 8$ & 181 & 171 & 179 & 4.9 \\
\hline $\mathrm{ME}$ deficit $(\mathrm{MJ} / \mathrm{d})$ & 55 & 50 & 60 & 6.5 & 25 & 22 & 25 & 6.0 \\
\hline Milk yield (kg/d) & $24 \cdot 9$ & 23.8 & $25 \cdot 0$ & 0.9 & $29 \cdot 4$ & $27 \cdot 6$ & 28.9 . & 0.9 \\
\hline FCM yield $(\mathrm{kg} / \mathrm{d})$ & $27 \cdot 7$ & $26 \cdot 8$ & 27.8 & $1 \cdot 1$ & $28 \cdot 7$ & $27 \cdot 2$ & $28 \cdot 7$ & 1.0 \\
\hline Milk fat $(\mathrm{g} / \mathrm{kg})$ & 48 & 49 & 48 & 1.6 & 38 & 39 & 40 & $1 \cdot 2$ \\
\hline Total solids $(\mathrm{g} / \mathrm{kg})$ & 142 & 144 & 142 & 1.9 & 129 & 130 & 129 & $2 \cdot 0$ \\
\hline Milk N (g/kg) & $6 \cdot 3$ & $6 \cdot 3$ & $6 \cdot 0$ & 0.13 & 5.5 & 5.6 & $5 \cdot 4$ & 0.13 \\
\hline
\end{tabular}

Table 4. Expt 3. Estimated metabolizable energy (ME) intakes and deficits relative to ME requirements for zero energy balance during weeks 2-12 of lactation for cows on diets containing groundnut meal $(G)$ or fish meal $(F)$ and consumed at two levels of ME intake ( $H$ and $L$ )

(Means for groups of nine cows)

\begin{tabular}{lccccccc}
\hline & \multicolumn{3}{c}{ ME intake (MJ/d) } & & ME deficit (MJ/d) \\
\cline { 2 - 7 } Weeks... & $2-4$ & $5-8$ & $9-12$ & $2-4$ & $5-8$ & $9-12$ \\
Diet & & & & & & \\
\hline HG & 163 & 173 & 174 & 48 & 29 & 13 \\
HF & 158 & 179 & 188 & 52 & 21 & $-3^{*}$ \\
LG & 127 & 133 & 137 & 61 & 44 & 29 \\
LF & 129 & 134 & 141 & 72 & 52 & 39 \\
SEM (df 32) & 5.7 & 6.3 & 5.6 & 6.9 & 5.9 & $5 \cdot 1$ \\
\hline
\end{tabular}

* ME surplus to requirement.

greater on the low-concentrate diets with frequencies of 0.4 and 0.8 per cow on diets LG and LF respectively. From the mean DOM values (Table 1), and making the same assumptions as for Expt 2, the ME concentrations for diets $\mathrm{HG}, \mathrm{HF}, \mathrm{LG}$ and LF were calculated to be $11 \cdot 0,10 \cdot 8,10.4$ and $10.3 \mathrm{MJ} / \mathrm{kg}$ respectively.

From the values for ME intake in Table 4 it can be seen that there were substantial differences between the $H$ and $L$ diets; there were no systematic differences in intake according to protein source but the cows on diet HF achieved the highest intakes during the latter part of the experiment. The ME requirements were calculated from live weights and FCM yields each week, using the same factors as for Expt 2, and were subtracted from the ME intakes to give the ME excesses or deficits which are summarized in Table 4. At the start of lactation there were substantial deficits on all four diets. These decreased from week to week and were greater for the low-concentrate diets than for the high-concentrate diets. The cows on diet HF were eating in excess of their estimated requirements by week 10 , but 


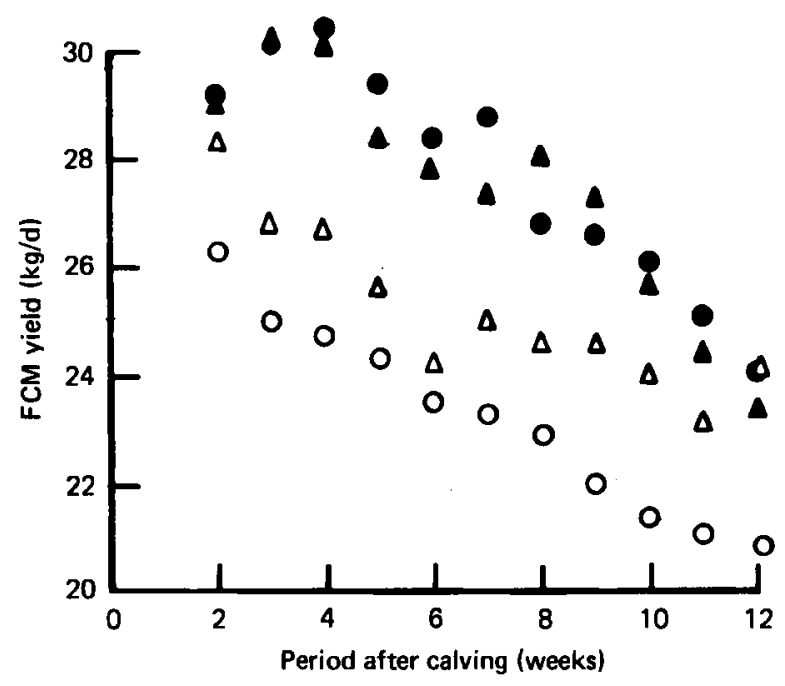

Fig. 1. The effect of feeding a high-concentrate $(\Delta, O)$ or a low-concentrate $(\Delta, O)$ diet with fish meal $(\Lambda, \Delta)$ or groundnut meal $(O, O)$ to dairy cows on yield of fat-corrected milk (FCM) during the first 12 weeks of lactation. (SEM $\pm 1 \cdot 15 \mathrm{~kg} / \mathrm{d}$; this value is applicable to any one of the weekly mean values.)

Table 5. Expt 3. Mean yields of milk and fat-corrected milk (FCM) during weeks 2-12 of lactation for groups of nine cows on diets containing groundnut meal $(G)$ or fish meal $(F)$, and consumed at two levels of metabolizable energy intake ( $H$ and $L)$

\begin{tabular}{lrcccccc}
\hline & \multicolumn{3}{c}{ Milk yield (kg/d) } & & \multicolumn{3}{c}{ FCM yield (kg/d) } \\
\cline { 2 - 4 } \cline { 6 - 8 } Weeks... & $2-4$ & $5-8$ & $9-12$ & & $2-4$ & $5-8$ & $9-12$ \\
Diet & & & & & & \\
\hline HG & 28.6 & 28.5 & 26.3 & & 29.9 & 28.4 & 25.4 \\
HF & 27.8 & 28.5 & 26.0 & & 29.8 & 27.9 & 25.0 \\
LG & 23.4 & 22.6 & 21.2 & & 25.4 & 23.5 & 21.4 \\
LF & 24.2 & 23.7 & 23.9 & & 27.3 & 24.9 & 23.9 \\
SEM (df 32) & 1.0 & 0.9 & 0.8 & & 1.1 & 0.9 & 0.7 \\
\hline
\end{tabular}

on diet HG were still in slight deficit on week 12 . The differences between the $H$ and $L$ diets in ME intake and deficits were statistically significant in all periods, but the differences between the fish meal and the groundnut diets were not significant.

The weekly yields of FCM plotted in Fig. 1 show that there were no systematic differences between diets HF and HG, but that the cows on diet LF gave consistently greater yields than those on LG. It can be seen that peak yields were achieved at approximately week 4 of lactation on the $\mathrm{H}$ diets but on the $\mathrm{L}$ diets yield tended to decrease beyond the 2 nd week. From the statistical analysis of the yields of milk and of FCM over three periods it can be seen (Table 5) that the $H v$. L comparison was significant $(P<0.001)$ in all periods, and that the differences in yield between diets HF and HG were nowhere significant. The differences in yield between diets LF and LG attained statistical significance $(P<0.05)$ during weeks 9-12. This difference was not attributed to the slightly higher incidence of ketosis on treatment LF. 
Table 6. Expt 3. Concentrations of fat, solids and nitrogen in milk during weeks 2-12 of lactation for cows on diets containing groundnut meal $(G)$ or fish meal $(F)$ and consumed at two levels of metabolizable energy intake $(H$ and $L)$

\begin{tabular}{|c|c|c|c|c|c|c|c|c|c|}
\hline \multirow[b]{2}{*}{$\begin{array}{l}\text { Weeks. } \\
\text { Diet }\end{array}$} & \multicolumn{3}{|c|}{ Milk fat $(\mathrm{g} / \mathrm{kg})$} & \multicolumn{3}{|c|}{ Total solids $(\mathrm{g} / \mathrm{kg})$} & \multicolumn{3}{|c|}{ Milk N (g/kg) } \\
\hline & $2-4$ & $5-8$ & $9-12$ & $2-4$ & $5-8$ & $9-12$ & $2-4$ & $5-8$ & $9-12$ \\
\hline HG & 43 & 40 & 38 & 137 & 128 & 125 & 5.2 & $4 \cdot 7$ & 4.7 \\
\hline $\mathrm{HF}$ & 45 & 39 & 38 & 142 & 127 & 125 & 5.6 & 5.0 & $5 \cdot 1$ \\
\hline LG & 46 & 43 & 41 & 136 & 127 & 128 & $5 \cdot 2$ & $4 \cdot 6$ & $4 \cdot 6$ \\
\hline LF & 49 & 43 & 40 & 141 & 126 & 126 & $5 \cdot 3$ & $4 \cdot 7$ & $4 \cdot 6$ \\
\hline SEM (df 32) & 2.0 & $1 \cdot 3$ & 1.3 & $2 \cdot 5$ & $2 \cdot 3$ & 1.9 & 0.10 & 0.07 & 0.09 \\
\hline
\end{tabular}

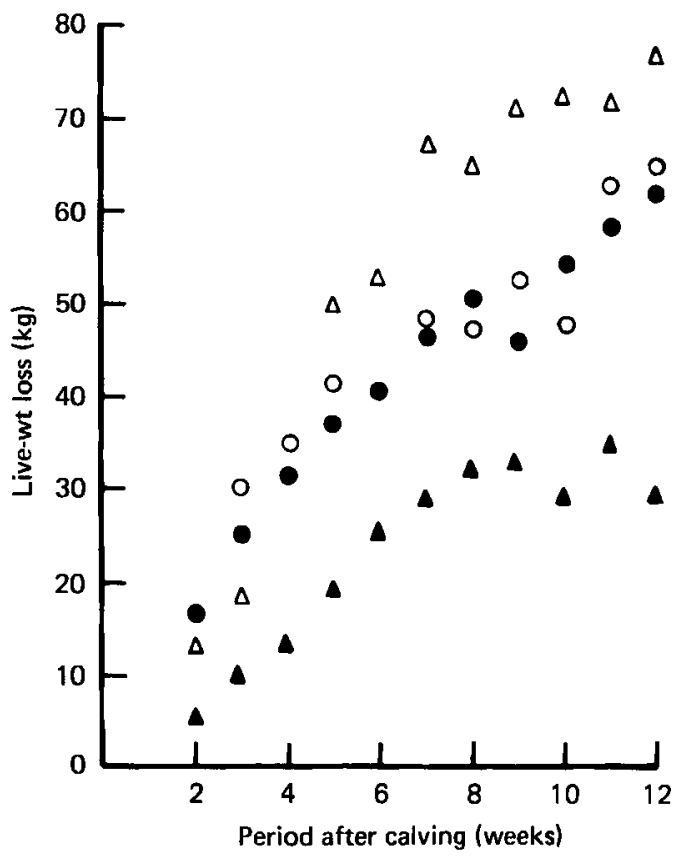

Fig. 2. The effect of feeding a high-concentrate $(\Delta, \boldsymbol{\theta})$ or a low-concentrate $(\triangle, O)$ diet with fish meal $(\Delta, \Delta)$ or groundnut meal $(\Theta, O)$ to dairy cows on live-weight loss $(\mathrm{kg})$ during the first 12 weeks of lactation. (SEM $\pm 9 \cdot 2$; this value is applicable to any one of the weekly mean values.)

Mean values for milk composition, over the same three periods, are given in Table 6 and show only small dietary effects. Fat content was higher for the low-concentrate diets than for the high-concentrate diets $(P<0.05)$ and $\mathrm{N}$ content was higher with diet HF than diet HG or the low-concentrate diets $(P<0.05)$.

The mean live-weight losses of the cows during the 12 weeks have been plotted in Fig. 2. They are greatest for the cows on diet LF and least for those on diet HF, in line with the calculated ME deficits. 


\section{DISCUSSION}

\section{Responses of dairy cows to protein of differing degradabilities}

The observations in Expt 1 that the cows responded to fish meal by increasing their milk yield confirmed earlier observations on infusion of casein into the abomasum of cows (Derrig et al. 1974; Ørskov et al. 1977) and goats (Ranawana \& Kelloway, 1977a, b). In view of these results it was surprising that there were no differences in milk yield or milk composition in Expt 2 when a highly-degradable source of protein (groundnut meal) was compared with a much-less-degradable protein source (fish meal), although the yields of the animals were much greater than those observed in Expt 1. The results of the 2nd experiment, however, agree with many of the results summarized by Clark (1975) where little or no change in milk yield on infusion of casein abomasally were noted, and with recent trials in which proteins of low degradability were fed to cows (Clay et al. 1978; Foldager \& Huber, 1978; Kaufmann \& Lupping, 1979).

When the results summarized by Clark (1975), together with the more recent results referred to and those obtained in Expt 1 and 2, are examined in detail it appears that while consistent increases in milk protein have been observed, increases in milk yield have been obtained by abomasal infusion of protein, or by feeding a relatively-undegraded protein mostly in experiments in which the cows were drawing heavily on body reserves because of food intake restrictions. Food intake was deliberately restricted in the studies of Ørskov et al. (1977) and an extent of undernutrition was calculated from the results of Derrig $e t$ $a l$. (1974) and Ranawana \& Kelloway $(1977 a, b)$. Undernutrition was also imposed in Expt 1 where intakes were restricted to avoid any uneaten feed. In Expt 2 and other experiments referred to, the cows were closer to energy equilibrium calculated from the food intake values.

The apparent differences in response to protein and to degradation characteristics of the proteins between cows drawing to a large extent on body reserves and cows near energy equilibrium, was the reason for carrying out Expt 3. Comparisons between protein sources of low and high degradability were made at two levels of ME intake which were achieved by varying concentrate: hay in the diets. When the ME intakes were high (H diets) the milk yields were much the same for diets containing either source of protein, but when the ME intakes were lower ( $L$ diets) the fish-meal diet (LF) appeared to stimulate a greater milk yield, a greater loss of body reserves (calculated) and a greater live-weight loss than the groundnut diet (LG).

If we assume that the energy deficiency in the instance of the low-concentrate diet was partly compensated by body fat mobilization then of course it could be argued that they were more deficient in protein since the protein concentrations in the two diets were similar. If this was the situation the cows on the low-concentrate diets could be expected to respond to differences in the amount of dietary protein reaching the small intestine, and hence the degradability of the protein might be of more critical importance. Using the various factors put forward by Roy et al. (1977) for the calculation of undegraded dietary protein requirement and a degradability of 0.85 for the barley and urea part of the diet, it can be estimated that to achieve a milk yield of $24 \mathrm{~kg} / \mathrm{d}$ with $4.6 \% \mathrm{~N}$ from the low-concentrate diets (LF) in weeks 9-12 with an ME intake of $140 \mathrm{MJ} / \mathrm{d}$, it would be necessary for the degradability of the protein supplement to be less than 0.36 . To achieve the same $\mathrm{N}$ yield in milk from the high-concentrate diets (HF) with an ME intake of $180 \mathrm{MJ} / \mathrm{d}$, it would be necessary for the degradability of the supplement to be less than $\mathbf{0 . 7 4}$. The calculations assume zero tissue protein mobilization. Although the numerical factors used may be considered tentative, the results of the calculation illustrate the point that the degradability of dietary protein is of more critical importance in periods of negative energy balance during lactation than when energy intake is close to requirement. 
The rate of outflow of small particles from the rumen of dairy cows is yet to be determined but from determinations of rumen degradation rate of the groundnut and fish meal used here, made on samples incubated in bags in the rumen of sheep, it was calculated that at a fractional hourly outflow rate of 0.04 the effective degradabilities would be 0.22 and 0.78 while at an outflow rate of 0.08 they would be 0.22 and 0.64 for the fish meal and groundnut meal respectively. The calculations of effective degradability were made as described by Ørskov \& McDonald (1979). This effect of flow rate is important since higher intakes also result in higher outflow rates. It follows that when food intake is high, to match milk production, the degradability of some protein supplements may be reduced, thus compensating for the high value for net protein: net energy requirement.

Live-weight loss and ME deficit. Alhough live-weight measurements are not considered to provide an accurate measure of the energy status of dairy cows, the series of weekly mean live weights shown in Fig. 2 appears to be reasonably consistent with the corresponding calculated mean ME deficits. This may be due in part to greater stability of gut content with complete-diet feeding. Assuming that body tissue was used for milk synthesis with a conversion efficiency of 0.82 (Moe et al. 1970), which is higher than the value assumed for ME, the estimates of ME deficit can be converted to estimates of body tissue mobilization. Over weeks 2-12 of lactation inclusively, the cows on diets HG, HF, LG and LF lost totals of $1721,1285,2643$ and $3230 \mathrm{MJ} /$ cow respectively, which would suggest energy values of $26,48,41$ and $42 \mathrm{MJ} / \mathrm{kg}$ for the corresponding live-weight losses. Values in excess of $39 \mathrm{MJ} / \mathrm{kg}$ are of course only possible if losses of fat are partly compensated for by gains in body water, but this is not at all unlikely.

The highest value was that for the HF diet, which must have provided an excess of protein in view of the degradability values and the similarity in milk yield between diets HF and HG. It is possible that on the HF diet the cows were gaining in tissue protein and accompanying water to a greater extent than on the other diets, even while they were still losing fat. The absolute values are of course dependent on the accuracy of the estimates of $\mathrm{ME}$ requirement.

Effects on milk composition. Both milk fat and milk protein concentrations were found to increase in response to post-ruminal influsion of protein (Ørskov et al. 1977). Other workers have reported similar observations (Derrig et al. 1974). The effects of protein sources in the present experiments were less clear-cut and cannot provide support for the earlier results.

The authors wish to express their gratitude to the Duthie Experimental Farm for their management and care of the dairy cows, especially Mr J. G. Gunn, J. Mair, F. Barrie, G. Fordyce and to Mr C. A. G. Tait for his technical assistance.

\section{REFEREN CES}

Association of Official Agricultural Chemists (1965). Official Methods of Analysis, 10th ed., p. 222. Washington, DC: Association of Official Agricultural Chemists.

Broster, W. H. (1972). Dairy Sci. Abstr. 34, 265.

Clark, J. H. (1975). J. Dairy Sci. 48, 1178.

Clay, A. B., Buckley, B. A., Hasballah, M. \& Satter, L. D. (1978). J. Dairy Sci. 61, 170.

Davidson, I., Mathieson, 1 \& Boyne, A. W. (1970). Analyst, Lond. 13, 461.

Derrig, R. G., Clark, J. H. \& Davis, C. L. (1974). J. Nutr. 104, 151.

Flatt, W. P., Moe, P. W., Munson, A. W. \& Cooper, T. (1967). In Energy Metabolism in Farm Animals, p. 235

[K. L. Blaxter, G. Thorbek and J. Kielanowski, editors]. Newcastle: Oriel Press Ltd.

Foldager, J. \& Huber, J. T. (1978). J. Dairy Sci. 61, 173.

Gaines, W. L. \& Overman, O. R. (1938). J. Dairy Sci. 21, 261.

Kaufmann, W. (1979). In Feeding Strategies for the High Yielding Dairy Cow, p. 90 [W. H. Broster and H. Swan, editors]. London: Granada Publishing Ltd.

Kaufmann, W. \& Lupping, W. (1979). Z. Tierphysiol. Tierernahr. Futtermittelk 41, 202. 
Moe, P. W., Tyrrell, H. F. \& Flatt, W. P. (1970). In Energy Metabolism of Farm Animals, p. 65 [A. Schurch and C. Wenk, editors]. Zurich: Juris Verlag.

Oldham, J. D. \& Sutton, J. D. (1979). In Feeding Strategies for the High Yielding Dairy Cow, p. 114 [W. H. Broster and H. Swan, editors]. London: Granada Publishing Ltd.

Ørskov, E. R. (1977). Wld Rev. Nutr. Diet. 26, 229.

Grskov, E. R., Grubb, D. A. \& Kay, R. N. B. (1977). Br. J. Nutr. 38, 397.

Grskov, E. R. \& McDonald, I. (1979). J. agric. sci., Camb. 92, 499.

Ranawana, S. S. E. \& Kelloway, R. C. (1977a). Br. J. Nutr. 37, 67.

Ranawana, S. S. E. \& Kelloway, R. C. (1977b). Br. J. Nutr. 37, 395.

Robinson, J. J., Fraser, C., Gill, J. C. \& McHattie, I. (1974). Anim. Prod. 19, 331.

Roy, J. H. B., Balch, C. C., Miller, E. R., Ørskov, E. R. \& Smith, R. H. (1977). In Protein Metabolism and Nutrition, p. 126 [S. Taminga, editor]. Wageningen Centre for Agricultural Publishing and Documentation.

Swan, H. (1979). In Feeding Strategies for the High Yielding Dairy Cow, p. 49 [W. H. Broster and H. Swan, editors]. London: Granada Publishing Ltd.

Van Soest, P. J. (1963). J. Ass. off agric. Chem. 46, 829. 